\title{
Stosunek polityków Dyrektoriatu Ukraińskiej Republiki Ludowej w 1919 roku wobec Cerkwi prawosławnej
}

W trzecim okresie ukraińskiej państwowości od grudnia 1918 roku do końca 1919 roku władzę na Ukrainie przejęły ugrupowania narodowe. Początkowo liderem ugrupowania politycznego, które w wyniku zamachu stanu 14 grudnia 1918 roku doszło do władzy, był Włodzimierz Wynnyczenko. Jako socjalista z przekonań wykazywał negatywną postawę wobec Cerkwi, czym zniechęcił do siebie religijnie nastawionych polityków i kler ${ }^{1}$. Z kolei w lutym 1919 roku przywództwo w Dyrektoriacie przejął Symon Petlura. Jego głębokie nastawienie religijne sprawiło, że pełnił on rolę głównego pomysłodawcy w wyznaczaniu generalnej linii polityki cerkiewnej swojego rządu.

Symon Petlura pochodził z rodu kozacko-duchownego z Połtawy. Wykształcenie podstawowe zdobył w prawosławnej szkole parafialnej. W roku 1895 wstąpił do Połtawskiego Seminarium Duchownego. Jego kolega z seminarium w swoich wspomnieniach napisał, że Symon był osobą głęboko religijną. Wprawdzie interesował się popularnymi w tamtym czasie poglądami krytycznymi na religię, jednak nie wpłynęły one w sposób istotny na jego światopogląd ${ }^{2}$. Symon Petlura nie mógł kontynuować nauki, gdyż usunięto go z seminarium. Powodem skreślenia z listy alumnów seminarium prawdopodobnie było wstąpienie Petlury w 1890 roku do Ukraińskiej Partii Rewolucyjnej³.

Stojąc na czele państwa, wszelako sprzyjał udziałowi Cerkwi w różnych uroczystościach, świętach państwowych. Publicznie religijność Petlury zaobserwowano 19 grudnia 1918 roku, gdy podczas nabożeństwa na Placu Sofijskim w Kijowie padł na kolana, po czym jako pierwszy podszedł do całowania krzyża ${ }^{4}$.

1 Zob. szerzej: Історія релігії в Украӥні. Українське Православ'я, red. П. Колодний, Київ 1999, t. III, s. 363.

2 I. Людим, Симон Петлюра і Церква, „Українське Православне слово” 1979, nr 5, s. 30.

3 Ibidem.

4 Ibidem, s. 32. 
Przebywając na emigracji, S. Petlura przedstawił swoje poglądy na sprawy cerkiewne w listach do ministra wyznań profesora Iwana Ohienki. W liście z dnia 19 grudnia 1921 roku S. Petlura poparł ministra w dążeniu do uznania Patriarchy Ekumenicznego i nawiązania kontaktów z wszechświatowymi organizacjami cerkiewnymi. Podkreślał wielką wagę sprawy przełożenia ksiąg liturgicznych na język ukraiński, nad czym właśnie pracował I. Ohienko, zwłaszcza Liturgii Św. Jana Chryzostoma ${ }^{5}$. Największą uwagę w listach Petlura poświęcał kwestii autokefalii. Pisał:

Moim zdaniem, sprawa ta nie została rozwiązana przez działaczy cerkiewnych jak należy, nie jest skonkretyzowana [...]. Nasze marzenia o autokefalii i walka o nią nie sięgają dalej żądania własnego metropolity w stolicy, i nie wykraczają poza utworzenie wyższej rady cerkiewnej przy tym metropolicie ${ }^{6}$.

Konstatował, że zasadniczym błędem polityki wobec Cerkwi w okresie Hetmanatu było podporządkowanie młodej Cerkwi ukraińskiej patriarsze moskiewskiemu. Jako działacz państwowy stwierdzał, że taka zależność w przyszłości wcześniej czy później zahamowałaby rozwój myśli zarówno cerkiewnej, jak i politycznej narodu ukraińskiego. Za przykład godny do naśladowania Petlura podał Cerkiew serbską, która przez wprowadzenie autokefalii wsparła walkę o niepodległość państwa7. Skupiając uwagę na sprawie autokefalii, podkreślił, że uniezależnienie ukraińskiego episkopatu przez powołanie autonomicznej Metropolii Kijowskiej było niewystarczające w warunkach, gdy istniała zależność prawna od obcego ośrodka cerkiewnego. Według Petlury, podstawowym zadaniem było powołanie swojego ukraińskiego patriarchy. Zadaniem tego patriarchy byłoby utrzymywanie zewnętrznych kontaktów z innymi Cerkwiami prawosławnymi, powstałymi na terenach byłego Imperium Rosyjskiego. Wśród takich cerkwi S. Petlura widział Cerkiew gruzińską, białoruską, polską, łacińską, ormiańsko-gregoriańską .

Analiza poglądów religijnych S. Pelury pozwala wysnuć wniosek, że nie tylko rozumiał on znaczenie Cerkwi dla zapewnienia jedności narodu, ale także dołożył wielu starań w celu wcielenia w życie licznych ustaw i postanowień Dyrektoriatu w sprawach cerkiewnych, w których przygotowaniu brał czynny udział.

Należy wspomnieć, iż w składzie Dyrektoriatu, oprócz Symona Petlury, znaleźli się również inni aktywni zwolennicy ukraińskiego ruchu autokefalicznego,

5 С. Петлюра, 3 листа до Охієнка, Київ 1993, s. 213.

${ }^{6}$ Ibidem, s. 214.

7 Ibidem.

8 Ibidem, s. 215. 
m.in. Panas Andrijewski, Włodzimierz Czechiwski, Sergiusz Szełuchin. 26 grudnia 1918 roku została sformowana Rada Ministrów Dyrektoriatu, na czele której stanął W. Czechiwski - aktywny działacz Bractwa Świętych Cyryla i Metodego. Z kolei Sergiusz Szełuchin otrzymał w rządzie tekę ministra sprawiedliwości ${ }^{9}$.

W dniu 29 grudnia 1918 roku nastąpił podział obowiązków dotyczących koordynacji działalności ministerstw między członkami Dyrektoriatu; P. Andrijewski miał wyznaczyć szefów w Ministerstwach: Sprawiedliwości, Żywności, Kontroli oraz Wyznań ${ }^{10}$.

Trzeba podkreślić, iż mimo obecności w Dyrektoriacie zwolenników odbudowy religijnej, w rządzie były również silne wpływy antycerkiewne, co łączyło w tej kwestii okres Dyrektoriatu z okresem URL. Te okoliczności sprawiły, że 23 grudnia 1918 roku pod wpływem antyklerykała Wynnyczenki Dyrektoriat zdecydował o rozwiązaniu Ministerstwa Wyznań, a jego funkcje przekazał organom administracji centralnej do spraw wyznań w Ministerstwie Oświaty Ludowej. Następnego dnia W. Wynnyczenko wystąpił na posiedzeniu Rady Komisarzy, która do czasu obrania rządu pełniła jego funkcje, $\mathrm{z}$ wnioskiem o utworzenie zarządu do spraw kultów przy Ministerstwie Oświaty Ludowej na czele z Iwanem Łypą. Wynnyczenko nie uzyskał jednak poparcia, gdyż takie postawienie sprawy wywołało sprzeciw ukraińskich autokefalistów, wskutek czego rząd zmienił swoje stanowisko ${ }^{11}$.

Sprawa funkcjonowania Ministerstwa Wyznań znowu była rozpatrywana na posiedzeniu rządu 29 grudnia 1918 roku. Jej inicjatorem i referentem był premier W. Czechiwski. Premierowi, choć nie bez trudu, udało się przeforsować wniosek o pozostawieniu Ministerstwa Wyznań w strukturze rządu ${ }^{12}$. Na tymczasowego komisarza Ministerstwa Wyznań wyznaczono byłego ministra wyznań Lotockiego ${ }^{13}$.

Piastując stanowisko komisarza Ministerstwa Wyznań, Łotocki kontynuował działania rozpoczęte w okresie Hetmanatu. Różnica w jego podejściu polegała na większym zdeterminowaniu i zaostrzeniu polityki wobec Cerkwi oraz jej hierarchii.

W grudniu 1918 roku do ks. biskupa Nikodema (Krotowa), wikariusza kijowskiego został skierowany list, w którym Komisarz wyraził swoje oburzenie z powodu treści, jakie zawierał diecezjalny organ prasowy „Kijowski Biuletyn Prawosławny”. Łotocki podkreślał, że „Biuletyn” na wskroś przesiąknięty był duchem nietolerancji i tendencyjnej wrogości wobec organizowania kwestii życia

9 Centralne Państwowe Archiwum Wyższych Organów Władzy w Kijowie (dalej CPAWOW), zespół 1065, opis 1, sprawa 2, arkusz (w j. ukr. - strona) 25.

10 Ibidem.

11 CPAWOW, z. 1065 , o. 1, s. 2, a 2.

12 Ibidem, a. 15.

13 О. Лотоцький, Сторінки минулого, Нью-Йорк 1966, t. 4, s. 9. 
cerkiewno-narodowego na Ukrainie i działalności osób, które chciały odrodzenia Ukraińskiej Cerkwi Narodowej. Jego zdaniem, wspomniane czasopismo krzewiło wśród duchowieństwa i wiernych wrogie nastawienie do takich zasad, które powinny stanowić podwaliny cerkiewnego życia na Ukrainie. Komisarz polecił ks. biskupowi Nikodemowi usunięcie ze stanowiska redaktora „Biuletynu” Dymytra Skrynczenkę za jego szkodliwą działalność publicystyczną. Biskupowi powierzono misję niedopuszczenia do dalszego krzewienia przez „Kijowski Biuletyn Prawosławny” idei wrogich odrodzeniu Cerkwi narodowej na Ukrainie ${ }^{14}$.

Łotocki nie zdążył wiele zdziałać, gdyż 4 stycznia 1919 roku rząd Czechiwskiego wyznaczył nowego ministra wyznań. Został nim Iwan Łypa ${ }^{15}$. Wiceministrem urzędu został Konstanty Mirowicz, posiadający duże doświadczenie w pracy w Ministerstwie Wyznań w okresie Państwa Ukraińskiego ${ }^{16}$.

Siedzibą Ministerstwa Wyznań był Dom Metropolitalny przy katedrze św. Sofii Mądrości Bożej. Struktura Ministerstwa na początku pozostała bez zmian i odpowiadała schematowi przyjętemu w okresie Hetmanatu. Urząd składał się z czterech resortów: Departamentu Spraw Ogólnych, Departamentu Cerkwi Prawosławnej, Departamentu Innych Wyznań oraz Departamentu Oświaty Religijnej. Nic się też nie zmieniło w harmonogramie pracy Ministerstwa ${ }^{17}$.

Komisarz Ministerstwa Wyznań Łotocki zdał swoją legitymację do Departamentu Spraw Ogólnych i 17 stycznia 1919 roku został oddelegowany do sprawowania funkcji ambasadora w Turcji (w randze ministra $\mathrm{z}$ ramienia Dyrektoriatu) ze specjalną misją szukania poparcia Patriarchy Konstantynopolitańskiego w sprawie uznania przez Cerkwie Wschodnie autokefalii Ukraińskiej Cerkwi Prawosławnej ${ }^{18}$. Pisał o swej nominacji:

Dyrektoriat podjął decyzję o wysłaniu do Konstantynopola nowego składu Ambasady, ponieważ powołany przez Hetmana ambasador M. Sykowkin wraz z upadkiem Hetmanatu zają stanowisko wrogie wobec Dyrektoriatu. Prezes Rady Ministrów W. Czechiwski dodatkowo obstawał za planem uznania przez Patriarchat Konstantynopolitański autokefalii Cerkwi Ukraińskiej [...]? ${ }^{19}$

Ministerstwo Wyznań postanowieniem Rady Ministrów 11 stycznia 1919 roku zostało przemianowane na Ministerstwo Kultów ${ }^{20}$. Dyrektoriat 14 stycznia

14 CPAWOW, z. 1072 , o. 1, s. 11, a 126.

15 Łotocki tłumaczył swą dymisję polityką kadrową Dyrektoriatu: stanowiska w rządzie mogli obejmować wyłącznie socjaliści. Patrz: О. Лотоцький, Сторінки минулого..., t. 4, s. 9.

16 Ibidem.

17 CPAWOW, z. 1072 , o. 1, s. 48, a. 1; s. 15, a. 73; s. 16, a. 48; z. 1063, o. 2, s. 2, a. 12.

18 Н. Плічковський, Нарис історії українької православної иеркви, Сідней 1988, s. 82.

19 О. Лотоцький, Сторінки минулого..., t. 4, s. 9.

20 CPAWOW, z. 1072 , o. 1, s. 15 , a. 14. 
wydał postanowienie o niezwłocznym zwolnieniu wszystkich urzędników, powołanych w okresie Hetmanatu. Nieco wcześniej, 8 stycznia 1919 roku, Najwyższa Komisja Śledcza zwróciła się do ministra wyznań z prośbą o nadesłanie materiałów na temat działalności politycznej byłych pracowników urzędu oraz ich najbliższych współpracowników ${ }^{21}$.

Uzupełnieniem weryfikacji pracowników ministerialnych służyć miał nakaz ministra Łypy z dnia 20 stycznia 1919 roku, uzależniający mianowanie nowych osób na stanowiska w urzędzie od rekomendacji przedstawicieli rządu ${ }^{22}$. Urzędnicy, którzy wyrazili chęć dalszej pracy w Ministerstwie Kultów, musieli składać odpowiednie oświadczenia o chęci kontynuowania pracy na zajmowanym stanowisku. Należy przy tym podkreślić, że wymiana kadr w Ministerstwie Kultów odbywała się ewolucyjnie. Szybkie zmiany zaszły tylko w kierownictwie Ministerstwa. Fakt pozostawienia na służbie urzędników rządu hetmańskiego mających spore doświadczenie zawodowe świadczy o tym, jak trudno było od razu wymienić wszystkich urzędników administracji państwowej. Można z pewnością stwierdzić, iż nakaz zwolnienia poprzednich pracowników Ministerstwa Wyznań miał niewiele wspólnego z rzeczywistym usprawnieniem pracy urzędu i był podyktowany wyłącznie względami politycznymi.

Kolejną przyczyną związaną z wymianą kadr w Ministerstwie Wyznań były częste przeprowadzki rządu, wskutek czego urzędnicy resortu musieli niejednokrotnie zmieniać miejsce zamieszkania. Niewątpliwie wymagało to poświęcenia i oddania sprawie. Wszystkie wspomniane okoliczności powodowały dużą rotację funkcjonariuszy urzędu, która wynosiła ok. $10 \%$ w skali rocznej ${ }^{23}$. W składzie personalnym Ministerstwa planowano zatrudnienie 188 urzędników etatowych, na których roczne utrzymanie z budżetu państwa planowano wyasygnować 1160900 karbowańców 24.

Trzeba jednakże zaznaczyć, że zaproponowane stanowiska etatowe nigdy nie zostały obsadzone. Najwięcej obsadzonych stanowisk było w przededniu przeprowadzki Ministerstwa z Kijowa do Kamieńca Podolskiego i liczyło ok. 160 pracowników, z których tylko 30 zgodziło się na ewakuacjęe25. W administracji Ministerstwa Kultów niekiedy pozostawało do $80 \%$ wakatów.

Nieustające przeprowadzki Dyrektoriatu nie sprzyjały, rzecz jasna, rozwijaniu działalności instytucji państwowych. Niekiedy liczba etatów osiągała poziom krytyczny. Na przykład, 11 czerwca 1920 roku w Ministerstwie Wyznań pracowało 6 urzędników²6, a 24 lutego 1921 roku w składzie Ministerstwa,

21 Ibidem, s. 11, a. 35.

22 Ibidem, z. 1071, o. 1, s. 409, a. 71.

23 Ibidem, z. 1072, o. 1, s. 4, a. 35.

24 Ibidem, s. 19, a. 22.

25 W wyników ofensywy bolszewików rząd Dyrektoriatu często musiał opuszczać Kijów.

26 CPAWOW, z. 1072, o. 1, s. 4, a. 9. 
które ewakuowało się z Kamieńca Podolskiego za granicę Ukrainy (14 listopada 1920 roku), były jedynie dwie osoby: pełniący obowiązki dyrektora Polikarp Sikorski i starszy referent $Ł$. Kensicki ${ }^{27}$.

W historiografii utwierdziło się przekonanie, iż działalność Ministerstwa Kultów za czasów I. Łypy w ciągu dziewięciu miesięcy 1919 roku cechował brak wystarczającej aktywności. Jednak dokumenty archiwalne świadczą, że w okresie jego szefostwa były podejmowane próby usprawnienia funkcjonowania administracji urzędu, skupienia w swoich rękach możliwości rozwiązania wszystkich najważniejszych problemów cerkiewnych, przygotowywania uchwał i projektów ustaw oraz zabezpieczenia ich wykonania.

Minister kultów systematycznie referował na posiedzeniach Rady Ministrów o wynikach działalności Ministerstwa, podstawowych programach i projektach. Niestety, sprawy cerkiewne nie zawsze znajdowały zrozumienie wśród najwyższego kierownictwa Dyrektoriatu. Niektórzy z nich uważali, że sprawa Cerkwi ukraińskiej nie zasługuje na uwagę. Znamienny jest fakt, że 25 kwietnia 1919 roku na posiedzeniu Gabinetu Ministrów minister pracy wystąpił z wnioskiem o zlikwidowanie Ministerstwa Kultów i przekazanie jego uprawnień do Ministerstwa Spraw Wewnętrznych, jak to było w okresie URL. Jednakże omówienie tej kwestii odłożono i więcej do niej nie wracano ${ }^{28}$.

Wspomnieć też trzeba o prowadzeniu przez ministra Łypę konsekwentnej polityki ukrainizacji swojego resortu. Jego działania w tej materii współgrały z powszechnie obowiązującym nurtem ukrainizacji całej administracji państwowej. Budowanie państwa na silnej podstawie narodowej stanowiło kluczowy element ideologii Dyrektoriatu. W związku z tym, 25 stycznia 1919 roku w Ministerstwie Kultów wydano okólnik zobowiązujący urzędników do posługiwania się językiem ukraińskim. W dokumencie podkreślano: „W Ukraińskiej Republice Ludowej za język państwowy uważa się tylko język ukraiński”29. Zaznaczano też, że wszystkie oficjalne spotkania powinny były się odbywać wyłącznie w języku ukraińskim. Wspomniano również o tym, iż instytucje cerkiewne kontynuowały przestrzeganie starych wzorców i we wszystkich sprawach posługiwały się językiem rosyjskim. Dlatego pismo nakładało na duchowieństwo surowy obowiązek posługiwania się wyłącznie językiem ukraińskim w celu sporządzania oświadczeń, podań, prowadzenia spraw śledczych, całej biurowości cerkiewnej, korespondencji, a w szczególności prowadzenia ksiąg metrykalnych, jak również wydawania drukiem diecezjalnych organów prasowych ${ }^{30}$.

\footnotetext{
27 Ibidem.

28 Ibidem, z. 3305, o. 1, s. 7, a. 27.

29 Ibidem, z. 1072 , o. 1, s. 93, a. 1.

30 Ibidem.
} 
Minister kultów skupiał znaczną uwagę na ulepszaniu pracy urzędników Ministerstwa i podtrzymaniu należytej dyscypliny. W związku z tym, 17 stycznia 1919 roku I. Łypa podpisał rozporządzenie, w którym zwracał uwagę urzędników i wszystkich współpracowników Ministerstwa Kultów na konieczność wytężonej pracy na rzecz ukraińskiej republiki i jej narodu. Minister moralizował: „Na nas spoczywa święty obowiązek pomocy Państwu w jego odbudowie. I dlatego wszyscy powinni wykonywać swoją pracę jak najlepiej”31. Dyrektorzy departamentów zostali zobowiązani do informowania ministra o przyczynach niestawiania się w pracy urzędników. Zabroniono prywatnych rozmów w salach oraz pokojach służbowych; kontakty służbowe były dozwolone wyłącznie w wyznaczonych do tego godzinach. Ustalono codzienny dyżur w lokalu Ministerstwa do godziny dziewiętnastej ${ }^{32}$.

Oprócz usprawnienia pracy organów administracji państwowej, Dyrektoriat usiłował zbudować skuteczny pion zarządzania życiem cerkiewnym na Ukrainie, a także wesprzeć materialnie duchowieństwo i urzędników w regionach. W dokumentach finansowych Ministerstwa Kultów znajdujemy kosztorysy finansowania konsystorzy prawosławnych oraz duchowieństwa w regionach.

Jak świadczą dokumenty, sytuacja duchowieństwa i pracowników rządowych była niezwykle trudna. W liście do ministra kultów, skierowanym pod koniec 1918 roku przez stowarzyszenie pracowników wszystkich instytucji rządowych i duchowieństwa miasta Staroduba zwrócono uwagę na ciężkie położenie materialne wszystkich kategorii urzędników państwowych i duchowieństwa. Starodub jako miasto przygraniczne zaznawało ciągłego ucisku ze strony władzy radzieckiej, wskutek czego wielu urzędników państwowych wyjeżdżało w głąb kraju. W mieście rozpowszechniła się spekulacja, wzrosły ceny produktów żywnościowych, koszty pracy, ceny mieszkań i paliwa. Pud chleba kosztował 150 karbowańców ${ }^{33}$, podczas gdy pensja nauczyciela wynosiła od 250 do 350 karbowańców miesięcznie. Większości pracowników sfery budżetowej groził głód. List kończył się prośbą o wyasygnowanie odpowiednich środków na różne potrzeby ${ }^{34}$.

Podobna sytuacja miała miejsce $w$ innych regionach Ukrainy. W związku z powyższym, Ministerstwo Kultów stosowało środki zaradcze, asygnując odpowiednie finanse na utrzymanie duchowieństwa i konsystorzy. Trzeba zaznaczyć, że środki te nie były wystarczające, szczególnie w porównaniu z okresem Hetmanatu. Na przykład, w 1919 roku na działalność konsystorzy wydzielono 181920 karbowańców, co stanowiło sumę prawie pięciokrotnie niższą

\footnotetext{
31 Ibidem, s. 17, a. 60.

32 Ibidem.

33 Pud - rosyjska jednostka wagowa stosowana w okresie carskim i porewolucyjnym, 1 pud $=16,38 \mathrm{~kg}$.

34 Ibidem, z. 1072, o. 1, s. 11, a. 91.
} 
niż w 1918 roku. Dane zjawisko można tłumaczyć nie tyle obniżeniem potencjału ekonomicznego kraju, co stopniową utratą władzy Dyrektoriatu w regionach Ukrainy. Niemniej jednak, finansowanie monasterów pozostawało na poziomie z 1918 roku i wynosiło 123925 karbowańców. Finansowanie prawosławnego duchowieństwa nieco uległo zmniejszeniu w porównaniu z rokiem 1918 i stanowiło 4094646 karbowańców ${ }^{35}$.

Ministerstwo Kultów dokładało wielu starań, aby chronić kadry duchownych ukraińskich na terytoriach nienależących do Dyrektoriatu. Szczególnie wielkiego rozgłosu nabrało aresztowanie przez władze Rzeczpospolitej Polskiej ks. S. Werżańskiego w miejscowości Kryłów (okolice Hrubieszowa) w drugiej połowie grudnia 1918 roku. Polska strona uzasadniała areszt tym, że po powrocie z ewakuacji duchowny, zebrawszy parafian, rozdawał zabronione książki. Stało się to powodem oskarżenia ks. Werżańskiego o zdradę państwa i oddania go pod wojskowy sąd polowy. Aresztowanego trzymano w chełmskim więzieniu. Minister Kultów podtrzymał sprzeciw Chełmskiej Rady Diecezjalnej z powodu aresztowania ks. Werżańskiego, a także zwrócił się do ministra spraw zagranicznych $\mathrm{z}$ wnioskiem o interwencję u polskiego ambasadora w tej sprawie ${ }^{36}$.

$\mathrm{W}$ celu zapoznania się z działalnością wewnętrzną Ministerstwa Wyznań wydawano biuletyn, w którym publikowano materiały o najważniejszych problemach działalności Ministerstwa, decyzje ministra, bieżące sprawy departamentów, projekty ustaw, a także informacje o wprowadzeniu w życie przyjętych uchwał.

W strukturze Ministerstwa działało Biuro Informacyjne, które zbierało i uogólniało informacje na temat życia cerkiewnego, prowadziło prace analityczne, jak również podawało do wiadomości regionalnych organów cerkiewnych decyzje organów państwa odnośnie Cerkwi. Ministerstwo 31 grudnia 1918 roku prenumerowało praktycznie wszystkie periodyki, które wychodziły na Ukrainie i poza jej granicami. Wykaz liczył ponad sześćdziesiąt tytułów, wśród których były nie tylko gazety i czasopisma cerkiewne „Wiara i Państwo”, „Wołyń Prawosławny”, „Kijowski Dziennik Prawosławny”, „Cerkiewny Dziennik Zaporoża”, ale również świeckie gazety i czasopisma o tematyce społeczno-politycznej: „Odrodzenie”, „Gazeta Robotnicza”, „Nowa Rada”, „Głos Południa”, „Nasze Słowo”. Świadczy to o dobrej orientacji Ministerstwa w zagadnieniach związanych z bieżącym życiem społeczno-politycznym i cerkiewnym na Ukrainie ${ }^{37}$.

Jednym z kontrowersyjnych posunięć Dyrektoriatu, zasługującym na bliższe omówienie, było przyjęcie ustawy o Wyższej Władzy Cerkiewnej w Ukraińskiej

35 Ibidem, s. 19, a. 34. Por. s. 130 rozprawy.

36 І. Власовський, Нарис історії Української Православної Церкви, Бавнд-Брук 1990, t. 4, s. 87.

37 О. Ігнатуша, Документи державних архівів України з історії Української Автокефальної Православної Церкви (1917-1930рр.), „Архіви України” 1994, nr 1, s. 44-56. 
Autokefalicznej Cerkwi Prawosławnej 1 stycznia 1919 roku. W tej ustawie władze państwowe proklamowały autokefalię cerkiewną na Ukrainie ${ }^{38}$.

Łotocki zaznaczał, że ustawa Dyrektoriatu o autokefalii Ukraińskiej Cerkwi Prawosławnej z dnia 1 stycznia 1919 roku została ogłoszona w chwili, kiedy pełnił on funkcję Komisarza Ministerstwa Kultów. Istotne jest, że jej przyjęcie Łotocki zaliczał do własnych osiągnięć. Poglądy na sedno i sposoby uzyskania autokefalii Łotocki przedstawił w swoich pamiętnikach. Pisał:

Autokefalia oznacza niezależność pewnej cerkwi, jej niezależność od innej władzy cerkiewnej. Taka niezależność poszczególnych cerkwi jest właściwością Cerkwi prawosławnej. Kościół katolicki uznaje jedność kościoła ogólnoświatowego pod jedną władzą Biskupa Rzymu (Papieża) i dlatego w Kościele katolickim nie ma kościołów autokefalicznych. Obok tej, można powiedzieć, monarchicznej zasady ustroju kościelnego w Kościele katolickim, w Cerkwi prawosławnej obowiązuje ustrój soborowy - znów według analogii nie do końca dokładnej - ustrój konstytucyjny: zachowując jedność w organie wspólnym - soborze powszechnym, odrębne Cerkwie prawosławne, cerkwie narodowe, zachowują niezależność jedna od drugiej, jak niezależne odrębne państwa, posiadające jakiś organ wspólny w celu wzajemnego porozumienia ${ }^{39}$.

Cerkiew prawosławna, zdaniem Łotockiego, zasadę jedności cerkiewnej pojmuje przez pryzmat wspólnoty nauki o dogmacie oraz prawa kanonicznego. Przy czym, jedność cerkiewna nie obejmuje dziedziny administracyjnej, ponieważ autokefaliczne Cerkwie są niezależne w prawie obierania i wyniesienia hierarchów, w sprawie sądu cerkiewnego i administracji. W rozumowaniu Lotockiego, granice państwa stanowią podstawę do cerkiewnego podziału administracyjnego. W związku z tym, ustanowienie niezależności konkretnej Cerkwi w granicach danego terytorium powinno leżeć w gestii władzy politycznej. Łotocki uzasadniał to następująco:

Tak więc, kiedy władze państwa uznają pewną cerkiew na pewnym terytorium za niezależną (autokefaliczną), to jest to akt uzasadniony oraz prawnie obowiązujący i sprzeciwić się jemu władza cerkiewna nie ma możliwości i nie ma do tego prawa, choćby ten akt naruszał interesy urzędników cerkiewnych ${ }^{40}$.

Wychodząc od faktów historycznych, Łotocki wysnuł wniosek, że źródłem autokefalii państwowej są władze państwa.

38 CPAWOW, z. 2208, o. 2, s. 2, a. 2.

39 О. Лотоцький, Сторінки минулого..., s. 14, 81.

40 Ibidem, s. 82. 
Według niego, Cerkiew ukraińska w Europie Wschodniej była pierwszą Cerkwią prawosławną, z której wiarę szerzono m.in. w Wielkim Księstwie Moskiewskim. Przez cały okres istnienia Ukraińska Cerkiew Prawosławna wywierała pozytywny wpływ na cerkwie-satelity, pozostając jednocześnie niezależną. Przyłączenie Cerkwi ukraińskiej do Cerkwi moskiewskiej w wyniku zjednoczenia politycznego Ukrainy i Rosji Łotocki uznawał za antykanoniczne i sprzecznie z wolą duchowieństwa i narodu Ukrainy ${ }^{41}$.

Wychodząc z przedstawionych założen, Łotocki twierdził, że ustawa Dyrektoriatu z dnia 1 stycznia 1919 roku była prawnie usankcjonowana i odpowiadała potrzebom życia politycznego oraz historii.

Warto przytoczyć pełny tekst ustawy o autokefalii, aby zapoznać się z jej kluczowymi postanowieniami oraz duchem, w jakim została ona sporządzona. Ustawa stanowiła:

1. Najwyższa władza cerkiewna na Ukrainie - ustawodawcza, prawna i administracyjna ma należeć do Powszechnego Ukraińskiego Soboru Cerkiewnego; jego postanowienia, w tym dotyczące stosunków państwowo-cerkiewnych lub wymagające nakładów finansowych Skarbu Państwa, mają być zgłaszane w celu ich rozpatrzenia oraz zatwierdzenia przez państwowe organy ustawodawcze.

2. Do kierowania sprawami Ukraińskiej Autokefalicznej Cerkwi Prawosławnej zostanie utworzony Ukraiński Synod Cerkiewny; w jego składzie będzie dwóch biskupów, jeden protojerej ${ }^{42}$, jeden ksiądz, jeden diakon, trzech świeckich, a także jeden ks. kapelan z Departamentu Wojskowego. Do czasu zwołania Soboru, który wybierze członków Synodu oraz zgłosi ich listę w celu uchwalenia przez Rząd, członkowie Synodu Cerkiewnego zostaną wyznaczeni przez Ukraiński Najwyższy Rząd Republikański.

3. Zakres uprawnień Synodu będzie obejmować zagadnienia: a) religijne, b) administracyjne, c) gospodarcze, d) oświatowe, e) kontroli i rewizji.

4. Synod Ukraiński będzie zbierać się w obecności przedstawiciela Rządu Republikańskiego, wyznaczonego przez Ministra i zwanego Przedstawicielem Państwa. W zakres jego obowiązków wchodzi: dostarczanie informacji, wyjaśnienie ustaw, nadzór nad wykonaniem ustaw oraz realizacją postanowień Synodu, które nie naruszają interesów Republiki. Przedstawiciel Państwa będzie miał prawo przekazywania protestów do Rady Ministrów.

5. Władza cerkiewna Autokefalicznej Cerkwi Prawosławnej wraz ze swoją administracją będzie utrzymywana ze środków finansowych Skarbu Państwa, zgodnie $\mathrm{z}$ etatem, który zostanie specjalnie w tym celu utworzony.

6. Ukraińska Cerkiew Autokefaliczna z Synodem i duchowieństwem w żadnym wypadku nie będzie podlegać Patriarsze Wszechrusi43 ${ }^{43}$.

41 Ibidem, s. 84.

42 Protojerej - przełożony kleru katedralnego w Cerkwi prawosławnej.

43 Czytaj: moskiewskiemu. 
7. Ukraiński Synod Cerkiewny opracuje zasady, określające jego działalność, w taki sam sposób, jak te, związane ze zwołaniem Soboru Cerkiewnego. Zasady te nabiorą mocy prawnej po ich uchwaleniu przez Ukraiński Rząd Republikański ${ }^{44}$ (tłumaczenie - autor).

$\mathrm{Z}$ uchwalonej przez Dyrektoriat ustawy o autokefalii cerkiewnej z dnia 1 stycznia 1919 roku wynika, że ówczesny rząd nie przewidywał oddzielenia Cerkwi od państwa. Usiłował natomiast sprzyjać wspólnym działaniom dwóch czynników - świeckiego i duchownego. Jednocześnie stawało się oczywiste, że wpływ władzy państwowej w Cerkwi stawał się praktycznie nieograniczony.

Analiza ustawy o autokefalii pozwala wysnuć wniosek, że była ona wyraźnie niedopracowana. Niedługo po jej proklamowaniu minister kultów zwrócił się do rządu z prośbą o dokonanie korekty, w celu rozszerzenia zakresu kompetencji cerkiewnej władzy wykonawczej. Ministrowi Łypie chodziło o to, że w ustawie zabrakło zapisu o kompetencjach sądowych Synodu ${ }^{45}$. Pominięcie tak istotnej funkcji w dokumencie kluczowym dla niezależności cerkiewnej na Ukrainie świadczy o dużym pośpiechu, w jakim ustawa ta została opracowana.

Zerwanie więzów kanonicznych z patriarchą moskiewskim należy uznać, jak na ten czas, za rewolucyjne. Ten zapis w ustawie wyraźnie pokazuje, że władze Dyrektoriatu a priori odrzucały drogę pertraktacji z Moskwą. Stanowisko miejscowej hierarchii również nie było brane pod uwagę - najważniejszą kwestią stawały się interesy państwowe. Z kanonicznego punktu widzenia zerwanie z patriarchą moskiewskim było działaniem antycerkiewnym, gdyż podjęcie tego rodzaju decyzji leżało w gestii wyłącznie ukraińskiego episkopatu ${ }^{46}$.

Departament Cerkwi Prawosławnej 11 stycznia 1919 roku telegrafem rozesłał powiadomienie do wszystkich biskupów Ukrainy, aby wprowadzili w życie postanowienia ustawy o autokefalii we wszystkich diecezjach oraz zaprzestali podczas nabożeństw odmawiać modlitwy w intencji patriarchy moskiewskiego Tichona, ks. metropolity Antoniego i ks. arcybiskupa Eulogiusza ${ }^{47}$. Dwóch ostatnich władze Dyrektoriatu uznały za wrogów ukraińskiej państwowości i zastosowały wobec nich areszt domowy ${ }^{48}$.

Należy zaznaczyć, że politycy Dyrektoriatu podejmowali konkretne działania mające na celu przejęcie władzy cerkiewnej na Ukrainie w swoje ręce. Na przykład, ks. biskupa Dionizego (Waledyńskiego) zobligowano do tego, aby zwolnił ze stanowiska ks. biskupa Nikodema (Krotowa), wikariusza kijowskiego,

\footnotetext{
44 CPAWOW, z. 2208, o. 2, s. 2, a. 2.

45 Ibidem, z. 1072, o. 1, s. 16, a. 41.

46 Por. kanony 12, 37 VI Soboru Powszechnego. Patrz: ks. A. Baron (opr.), Dokumenty Soborów Powszechnych, Kraków 2001, t. I, s. 321.

47 Ibidem.

48 І. Нагаєвський, Історія Української держави двадиятого століття, Київ 1994, s. 377.
} 
co zostało wykonane. W wyniku tego posunięcia diecezja kijowska pozostała bez kierującego, dlatego też Ministerstwo Kultów zwróciło się do Dyrektoriatu z prośbą o wyznaczenie biskupa zarządzającego tą diecezją ${ }^{49}$.

Władze ukraińskie zabiegały, aby na biskupa zarządzającego diecezją kijowską wyznaczono kandydata rządowego. Jednakże Kancelaria Biskupów uchyliła to żądanie, uzasadniając niemożliwość zwolnienia ks. biskupa Nikodema (Krotowa) bez sądu biskupów. W odpowiedzi kancelarii akcentowano fakt, iż tylko biskupi mają prawo wybierać nowego członka hierarchii. Na takie okoliczności władze zareagowały aresztem ks. biskupa Nikodema i przetransportowaniem go do monasteru bazyliańskiego w Buczaczu, gdzie przebywali Antoni i Eulogiusz. Ostatecznie biskupem kierującym sprawami diecezji kijowskiej został ks. biskup Nazariusz (Blinow), Rosjanin z pochodzenia ${ }^{50}$.

W celu realizacji ustawy o autokefalii minister kultów Łypa 16 stycznia 1919 roku wydał nakaz o utworzeniu przy Ministerstwie Kultów tymczasowej komisji do spraw sporządzenia projektu statutu Ukraińskiej Autokefalicznej Cerkwi Prawosławnej. Przewodniczącym komisji został Konstanty Mirowicz ${ }^{51}$.

Niemniej jednak wprowadzenie ustawy o autokefalii zależało przede wszystkim od stanowiska episkopatu. Dlatego też minister Łypa podjął trudne rozmowy z biskupami, usiłując uzyskać ich poparcie w sprawie powołania Ukraińskiego Synodu Cerkiewnego. W tym celu na wniosek ministra kultów zwołany został Sobór Biskupów Ukraińskich, który składał się z jednego arcybiskupa i pięciu wikariuszy. Sobór, uwzględniając fakt ogłoszenia autokefalii Cerkwi ukraińskiej, uznał za konieczne niestawianie przeszkód w tej sprawie i ze swojej strony postanowił dołożyć starań w celu utworzenia Synodu. Mimo tych deklaracji, biskupi nie podjęli żadnych wiążących decyzji odnośnie Synodu w obawie przed represjami ze strony patriarchy Tichona oraz ks. metropolity Antoniego ${ }^{52}$.

Brak aktywnej postawy episkopatu sprawił, że rząd Dyrektoriatu 23 stycznia 1919 roku sam wyznaczył członków Synodu. Była to decyzja kompromisowa, osiągnięta między władzami ukraińskimi a episkopatem. Spośród osób duchownych w składzie Synodu znaleźli się ks. arcybiskup Agapit (Wiszniewski), ks. biskup Dionizy (Waledyński), ks. W. Łypkiwski, ks. M. Kramarenko, ks. kapelan A. Matijuk, ks. diakon O. Durdukowski ${ }^{53}$. W wyniku ekspansji bolszewików rząd Dyrektoriatu 2 lutego 1919 roku zmuszony został do opuszczenia Kijowa. Minister kultów zaproponował wraz z urzędnikami rządowymi ewakuowanie członków Synodu, ale tę propozycję odrzuciła lewicowa część Rady Ministrów. Po

\footnotetext{
49 CPAWOW, z. 1072, o. 1, s. 16, a. 41.

50 I. Нагаєвський, Історія Української держави двадиятого століття..., s. 380.

51 CPAWOW, z. 1072 , o. 1, s. 16, a. 49.

52 І. Липа, Як я пішов у революиію: уривок із щоденника, Львів 1928, s. 95-99.

53 CPAWOW, z. 1072 , о. 1, s. 16, а. 91, por.: I. Липа, Як я пішов у революиію: уривок із щоденника..., s. 98.
} 
wyznaczeniu członków Synodu odbyło się tylko jedno jego posiedzenie inauguracyjne 26 stycznia 1918 roku. Żadnych istotnych decyzji ten organ podjąć nie zdążył, a po ewakuacji z Kijowa Synod przestał istnieć.

Po kilkumiesięcznych przeprowadzkach, w czerwcu 1919 roku rząd Dyrektoriatu ulokował się w Kamieńcu Podolskim. Tutaj Ministerstwo Kultów odnowiło swoją działalność pod kierownictwem wiceministra Mirowicza, który do września 1919 roku kontynuował realizację polityki ministra Łypy ${ }^{54}$. 16 września 1919 roku stanowisko ministra kultów objął prof. Iwan Ohienko, który przedtem pełnił funkcję szefa Ministerstwa Oświaty Ludowej. Stojąc na czele Ministerstwa Kultów, zwracał on uwagę na ważne kwestie reformy życia cerkiewnego. Uważał, że Ukraińska Cerkiew Prawosławna powinna była stać się jednym z najsilniejszych czynników ukraińskiej walki narodowowyzwoleńczej. Generalne podejście do zagadnień cerkiewnych przedstawia jego wypowiedź na jednym z posiedzeń Ministerstwa 28 października 1919 roku. Twierdził wówczas:

Gdzie jest nasza Cerkiew? Ja jej nie widzę, widzę tylko Cerkiew występującą przeciwko nam [...]. Wasze myśli skłaniają się ku oddzieleniu Cerkwi od państwa, ale stawać na tej drodze jest trochę za wcześnie. Stoję jedynie na gruncie państwowym. Cerkiew, którą mamy, nie pomaga nam. Nie przejawia ona bowiem swojej inicjatywy na rzecz Państwa Ukraińskiego. [...] Jako minister i obrońca interesów duchownych Cerkwi stwierdzam, iż tylko przy Cerkwi narodowej będziemy mieli państwo narodowe. Do tej pory państwo gnębiło Cerkiew, ale myślę też, że Cerkiew ta nie była ukraińska ${ }^{55}$.

W tych słowach został zawarty praktycznie cały program działalności Ministerstwa Kultów pod kierownictwem prof. I. Ohienki.

Ohienko 17 września 1919 roku zaproponował stworzenie organu doradczego przy ministrze kultów oraz zatwierdził jego skład tymczasowy. Projekt ustawy przyjęła Rada Ministrów, a 11 listopada 1919 roku Dyrektoriat uchwalił ustawę o utworzeniu Rady Ministra Wyznań. W skład Rady Ministra wchodziły 3 osoby (utrzymanie roczne każdej z tych osób stanowiło 24000 karbowańców), a także siedmiu członków nieetatowych ${ }^{56}$. Na swym pierwszym posiedzeniu Rada postanowiła zmienić nazwę Ministerstwa Kultów na poprzednią: Ministerstwo Wyznań. W uzasadnieniu decyzji podano argument, iż słowo „kult” było uważane za obce i mało zrozumiałe dla ludności ukraińskiej oraz mniej odpowiadało realiom ówczesnego życia społecznego niż słowo „wyznanie”. Decyzję o zmianie nazwy Ministerstwa Kultów na Ministerstwo Wyznań Rada Ministrów podjęła 18 września $1919 \mathrm{roku}^{57}$.

\footnotetext{
54 Історія релігії в Україні. Українське Православ'я..., s. 363.

55 CPAWOW, z. 1072, o. 1, s. 3, a. 55.

56 CPAWOW, z. 1072 , o. 1, s. 4, a. 7, 17, 18.

57 Ibidem.
} 
Według prof. I. Ohienki, utworzenie Rady miało aktywizować pracę Ministerstwa. W notatce służbowej na ten temat, minister mówił o braku kadr rządowych w aparacie Ministerstwa, ponieważ po wyjeździe z Kijowa w styczniu 1919 roku pozostało tam około stu urzędników, podczas gdy okoliczności wymagały zaangażowania większej liczby osób ${ }^{58}$.

W skład Rady Ministra Wyznań weszli profesorowie Wydziału Teologicznego Państwowego Uniwersytetu w Kamieńcu Podolskim oraz działacze społeczni, zarówno duchowni, jak i świeccy. Członkami Rady zostali ks. W. Łypkiwski, ks. J. Sicyński, ks. M. Kramarenko, ks. A. Maryczew, profesor W. Bidnow, W. Czechiwski oraz inni aktywni działacze narodowi ${ }^{59}$.

Protokoły posiedzeń Rady Ministra Wyznań świadczą o wielkiej intensywności realizowanych działań. Od 18 września do 8 listopada 1919 roku odbyło się dwadzieścia posiedzeń Rady, na których rozpatrzono 62 sprawy. Poruszane zagadnienia dotyczyły najróżniejszych aspektów życia i działalności zarówno organów państwowych, które zarządzały sprawami cerkiewnymi, jak i samej Cerkwi ${ }^{60}$.

W Ministerstwie Wyznań podkreślano konieczność krzewienia idei narodowych zarówno wśród duchowieństwa, jak i wiernych. W tym celu Rada Ministra Wyznań zaproponowała założenie własnego wydawnictwa w Kamieńcu Podolskim, które zajmowałoby się drukiem odpowiednich materiałów agitacyjnych. Ministerstwo Prasy wyraziło zgodę na udostępnienie w tym celu swojej drukarni. Uchwałę o utworzeniu tygodnika „Cerkiew Ukraińska” - organu prasowego Ministerstwa Wyznań, przyjęto 21 września 1919 roku $^{61}$.

Tygodnik miał składać się z dwóch części. W pierwszej części periodyku planowano publikowanie ustaw oraz innych państwowych aktów prawnych dotyczących Cerkwi, nakazów organów centralnych, zawiadomień; w drugiej kazań, artykułów na tematy społeczne, cerkiewne, dogmatyczne, teologiczne, historyczne i inne. Raz w miesiącu „Cerkiew Ukraińska” wychodziła z dodatkiem - spisem kazań na cały miesiąc, przeznaczonym do wykorzystania przez duchowieństwo. Redaktorem został ks. Sicyński, jego pomocnikiem prof. W. Bidnow, redaktorem kazań - ks. Łypkiwski. Nakład planowano na 5000 egzemplarzy ${ }^{62}$.

Minister I. Ohienko zwracał też uwagę na konieczność opracowania rozwiązań legislacyjnych, które stworzyłyby podstawy prawne do działalności podporządkowanych mu struktur, zwłaszcza konsystorzy i innych cerkiewnych organów zarządzania. Pod jego bezpośrednim kierownictwem do końca października 1919 roku opracowano szereg projektów ustaw, wśród których znalazły się: pro-

\footnotetext{
58 Ibidem, s. 2, a. 15.

59 Ibidem, s. 3, a. 1.

60 О. Лотоцький, Сторінки минулого..., s. 10-11.

61 Ibidem, s. 4, a. 11.

62 Ibidem, s. 3, a. 16.
} 
jekt o władzy diecezjalnej, statut parafialny, statut Ministerstwa Wyznań i przyszłego Synodu ${ }^{63}$.

Ważną sprawą w polityce nowego szefa Ministerstwa Wyznań była ukrainizacja Cerkwi. Charakterystyczne było to, że przebiegała ona pod bezpośrednim nadzorem Symona Petlury, podczas gdy na jej realizację rząd Dyrektoriatu we wrześniu 1919 roku wyasygnował 10000 karbowańców ${ }^{64}$. Kwestia ukrainizacji była szczegółowo rozpatrywana na czterech posiedzeniach Rady Ministra Wyznań we wrześniu i listopadzie 1919 roku. Faktycznie przez cały ten czas jej rozstrzygnięcie blokował ks. biskup Pimen (Piegow), który kategorycznie przeciwstawił się nowym rozwiązaniom Ministerstwa. Między ks. biskupem Pimenem a Ministerstwem Wyznań wokół ukrainizacji Cerkwi, którą minister wyznań I. Ohienko uważał za sprawę wielkiej wagi, rozgorzał ostry konflikt.

Pierwszym działaniem na rzecz ukrainizacji miało być wprowadzenie tzw. wymowy ukraińskiej w rycie liturgicznym. Rada Ministra Wyznań 22 września 1919 roku rozpatrzyła kwestię „O wymowie ukraińskiej podczas sprawowania Liturgii św. przez księży oraz czytaniu Pisma Świętego w języku ukraińskim”. Na posiedzeniu Rady Ohienko przedstawił argumenty uzasadniające konieczność przeprowadzenia reformy językowej. Minister zaznaczył, iż w związku z brakiem przekładu ukraińskiego ksiąg liturgicznych, Liturgia św. na Ukrainie miała być odprawiana z ukraińską wymową tekstu słowiańskiego. Warto zaznaczyć, że Cerkiew miała wówczas ukraiński przekład Nowego Testamentu. Sprawę natomiast hamował fakt, iż parafie prawosławne na Ukrainie nie zostały zaopatrzone w Ewangelię w języku ukraińskim. Wobec tego minister wyznań proponował rozesłać odpowiednie egzemplarze Pisma Świętego bezpośrednio do parafii ${ }^{65}$. Ohienko 24 września 1919 roku zobligował episkopat do opracowania w ciągu jednego miesiąca wymowy ukraińskiej w diecezjach. Dodatkowo apelował, aby na księży prawosławnych wyświęcano wyłącznie osoby mające ukraińskie pochodzenie i urodzone na Ukrainie.

Wprowadzenie wymowy ukraińskiej do słowiańskiego tekstu liturgicznego wymagało przeprowadzenia odpowiedniego przeszkolenia duchownych. Minister wyznań podejmował w związku z tym starania, aby zorganizować szeroką sieć kursów we wszystkich miastach powiatowych, podlegających kontroli władz Dyrektoriatu. Kursy miały objąć nie tylko duchowieństwo, ale również dyrygentów chórów cerkiewnych oraz wszystkie inne osoby zainteresowane. Na realizację tego celu planowano wydać 214000 karbowańców ${ }^{66}$. Z wnioskiem formalnym

63 Zob. szerzej: I. Огієнко, Рятування України. На тяжкій службі своєму народові, Вінніпег 1968, s. 98-193.

${ }^{64}$ CPAWOW, s. 25, a. 2.

65 CPAWOW, z. 1071, o. 1, s. 3, a. 11.

66 Ibidem, z. 1072, o. 1, s. 25, a. 6. 
organizacji kursów dla duchownych Ohienko wystąpił na posiedzeniu Rady Ministra Wyznań 22 września 1919 roku $^{67}$. Rada zaakceptowała wniosek i postanowiła rozpocząć pierwszy kurs ukrainizacyjny 29 września 1919 roku przy Uniwersytecie w Kamieńcu Podolskim. Odpowiednie zaproszenia Ministerstwo rozesłało do parafii przez konsystorz ${ }^{68}$.

Decyzją ministra wyznań z 27 września 1919 roku, kierownikiem kursu został prof. W. Bidnow. W jego kompetencji było ułożenie programu dydaktycznego i dobór kadry nauczycielskiej. Program ułożony przez prof. Bidnowa zakładał przeprowadzenie następujących wykładów: „Wymowa ukraińska” - 3 godz. lekcyjne, „Historia Cerkwi Ukraińskiej” - 3 godz. lekcyjne, „Historia Ukrainy” - 2 godz. lekcyjne, „Geografia Ukrainy” - 1 godz. lekcyjna, „Historia pisma ukraińskiego" - 2 godz. lekcyjne ${ }^{69}$.

Kursy rozpoczęły się 29 września i trwały trzy dni. Bezpośrednia organizacja zajęć spoczęła na Wydziale Teologicznym Uniwersytetu w Kamieńcu Podolskim. W wykładach udział wzięło 57 osób: 24 księży, 6 diakonów, 6 psalmistów, 15 alumnów seminariów duchownych oraz 6 osób świeckich ${ }^{70}$.

Organizowane przez Ministerstwo Wyznań kursy ukrainizacyjne świadczyły o realnych poczynaniach władz ukraińskich, podejmowanych w dziedzinie ukrainizacji Cerkwi. Dodatkowym posunięciem w tej dziedzinie było opracowanie planu ukrainizacji wymowy liturgicznej w regionach. Minister Ohienko zaproponował, aby wyznaczyć w każdym powiecie trzech koordynatorów odpowiedzialnych za ukrainizację wymowy liturgicznej. Kluczowym zadaniem koordynatora była praca edukacyjna z księżmi na wzór kursów organizowanych w Kamieńcu Podolskim.

Sprawa przekładu Pisma Świętego na język ukraiński była nader aktualna. Ohienko 15 września 1919 roku przygotował i zgłosił do Rady Ministrów projekt ustawy o przekładzie Pisma Świętego. Z kolei 20 września Rada Ministra Wyznań powołała specjalną Komisję do spraw przekładu Pisma Świętego. Przekład Biblii oraz innych ksiąg liturgicznych na język ukraiński został uznany za jeden z najważniejszych kierunków w polityce Dyrektoriatu. 27 października 1919 roku na realizację tego celu z budżetu państwa wyasygnowano 4 mln karbowańców ${ }^{71}$.

W wyniku prac Komisji do spraw przekładu Nowego Testamentu z języka greckiego na język ukraiński został przetłumaczony Nowy Testament. Pierwsza wersja tłumaczeniowa została opublikowana w niewielkim nakładzie przez

\footnotetext{
67 Ibidem, s. 3, a. 12.

68 Ibidem, z. 1072, o. 1, s. 3, a. 12.

69 Ibidem, a. 30.

70 Ibidem.

71 Ibidem, s. 3, a. 8.
} 
wydawnictwo Uniwersytetu w Kamieńcu Podolskim. Profesor Bidnow, jeden z członków Komisji relacjonuje, że wszystkie egzemplarze zostały zniszczone w 1920 roku przez bolszewików ${ }^{72}$.

Ministerstwo Wyznań usiłowało rozwiązywać również inne problemy, np. małżeństw mieszanych. Rzecz w tym, że do Ministerstwa docierały skargi na ks. biskupa Pimena (Piegowa), który rzekomo zabraniał swoim wiernym zawierania małżeństw z wyznawcami innych konfesji. Sprawa została poruszona na jednym z zebrań Rady Ministra Wyznań 3 listopada 1919 roku, o czym poinformowano rząd. Odpowiedź Rady Ministrów brzmiała: „Zakaz zawierania małżeństw mieszanych niezwłocznie odwołać"73.

Na porządku dziennym Ministerstwa Wyznań były też inne kwestie związane ze sprawami cywilnymi (metryki, śluby, rozwody i inne). Chodziło przede wszystkim o rozgraniczenie kompetencji państwowych i cerkiewnych oraz określenie stopnia prawomocności cerkiewnych aktów stanu cywilnego.

Rada Ministra Wyznań 29 września 1919 roku rozpatrzyła sprawę prowadzenia przez duchowieństwo ksiąg metrykalnych. Należało rozstrzygnąć pytanie: czy przekazać państwu prawo zapisów o urodzeniach czy pozostawić tę kompetencję Cerkwi? Argumentem na korzyść pozostawienia tego prawa Cerkwi był fakt, iż samorządy regionalne, do których zgodnie z projektem ustaw miała być przekazana sprawa zapisów metrykalnych, nie były dostatecznie do tego przygotowane. Zdaniem Rady, państwo mogło przejąć prowadzenie zapisów o urodzeniach, ale dotychczasowe księgi miały pozostać w Cerkwiach. W wyniku dyskusji postanowiono przyjąć model podwójnej ewidencji aktów metrykalnych, prowadzonej zarówno przez państwo, jak i cerkiew ${ }^{74}$. Podobnie rozwiązano sprawę zawierania małżeństw i udzielania rozwodów.

Dyrektoriat 4 lipca 1920 roku przyjął ustawę o rozwiązywaniu małżeństw. Przewidywała ona, że małżeństwo zawarte w Cerkwi może rozwiązać jedynie rada diecezjalna zgodnie $\mathrm{z}$ obowiązującymi normami. Postanowienie rady diecezjalnej uważane było za ostateczne i niewymagające zatwierdzenia przez biskupa lub inną władzę cerkiewną. Ministerstwo Wyznań miało być organem odwoławczym od decyzji rad cerkiewnych ${ }^{75}$.

W ten sposób w okresie Dyrektoriatu, w Ministerstwie Wyznań pod kierownictwem Łotockiego, I. Łypy i prof. I. Ohienki cały czas odbywał się proces kształtowania się aparatu Ministerstwa: prowadzono dobór i selekcję kadr wykorzystując potencjał Ministerstwa Wyznań Hetmanatu, tj. poprzedniej ekipy politycznej. Jednocześnie były realizowane konkretne działania mające na celu upo-

\footnotetext{
72 В. Біднов, Церковний рух на Поділлі, Warszawa 1924, s. 50.

73 CPAWOW, z. 1072, o. 1, s. 3, a. 76.

74 Ibidem, a. 17.

75 Ibidem, s. 25, a. 9.
} 
rządkowanie spraw cerkiewnych na Ukrainie. Ministerstwo miało realną władzę i usiłowało prowadzić politykę podporządkowania hierarchii cerkiewnej sprawom narodowym. Wraz z tym, w działalności Ministerstwa można było zaobserwować linię, która nie zawsze zbiegała się z przepisami prawa kanonicznego. Tak było też w przypadku ustawy o autokefalii, której postanowienia odbiegały od norm przyjętych w cerkiewnym prawie kanonicznym.

\section{The attitude of the Directorate of Ukraine' politicians towards the Orthodox Church in 1919}

In the third period of Ukrainian prerevolutionary statehood, called Directorate, national groups took over the authority. As a result of various events, in February 1919 Symon Petlura became the leader of the republic. One of the most revolutionary decisions of the Directorate consisted in adoption of the act of autocephaly of the Ukrainian Orthodox Church. Although the episcopate of the Ukrainian Orthodox Church boycotted this act, the Directorate strived hard to execute its resolutions. One of the most important Directorate's actions was sending to Constantinople a representative of O. Łotocki's government, with the mission of gaining the ecumenical patriarch's - Germanos V's support. A fast collapse of the new authority made it impossible for the Ukrainian nationals to achieve the main objective - the autocephaly of the Church.

Key words: Ukrainian Orthodox Church, 1917 revolution, national movement, autocephaly, Directorate

\section{Bibliografia}

\section{Źródła archiwalne}

Centralne Państwowe Archiwum Wyższych Organów Władzy w Kijowie (dalej CPAWOW), zespół 1063, opis 2, s. 2, a. 12; s. 11, a. 35.

CPAWOW, zespół 1065, opis 1, sprawa 2, arkusz (w j. ukr. - strona) 2, 25.

CPAWOW, zespół 1071, o. 1, s. 3, a. 11; s. 409, a. 71.

CPAWOW, zespół 1072, opis 1, s. 2, a. 15; s. 3, a. 8, 12, 17, 30, 55, 76; s. 4, a. 7, 17-18; s. 11 , a. 91,126 ; s. 4 , a. 9,35 ; s. 15 , a. 14,73 ; s. 16 , a. $41,48-49,91$; s. 17 , a. 60 ; s. 19 , a. 22,34 ; s. 25 , a. $2,6,9$; s. 48 , a. 1 ; s. 93 , a. 1 .

CPAWOW, zespół 2208, o. 2, s. 2, a. 2.

CPAWOW, zespół 3305, o. 1, s. 7, a. 27. 


\section{Literatura}

Baron A. (opr.), Dokumenty Soborów Powszechnych, t. I, Kraków 2001.

Біднов В., Церковний рух на Поділлі, Warszawa 1924.

Власовський І., Нарис історії Української Православної Церкви, t. 4, Бавнд-Брук 1990.

Нагаєвський І., Історія Української держави двадиятого століття, Київ 1994.

Ігнатуша О., Документи державних архівів України з історії Української Автокефальної Православної Церкви (1917-1930рр.), „Архіви України” 1994, nr 1.

Історія релігії в Україні. Українське Православ’я, red. П. Колодний, t. III, Київ 1999.

Липа І., Як я пішов у революиію: уривок із шоденника, Львів 1928.

Лотоцький О., Сторінки минулого, t. 4, Нью-Йорк 1966.

Людим І., Симон Петлюра і Церква, „Українське Православне слово” 1979, nr 5.

Огієнко І., Рятування України. На тяжкій службі своєму народові, Вінніпег 1968.

Петлюра С., 3 листа до Огієнка, Київ 1993.

Плічковський Н., Нарис історії украӥнської православної иеркви, Сідней 1988. 